\title{
Bank duties in lieu of account owner and cheque owner and its sanctions
}

\author{
Abasat Pour Mohammad ${ }^{1}$, Mehdi Abdollahi ${ }^{2}$ and Hoshang Mola Gholizadeh ${ }^{3}$ \\ 1 Corresponding Author: Assistant Professor, Department of Law, Maragheh Branch, Islamic Azad University, Maragheh, Iran. E-mail: \\ dr_a_p20@yahoo.com \\ 2 PhD Student, Department of Law, Maragheh Branch, Islamic Azad University, Maragheh, Iran. \\ 3 PhD Student, Department of Law, Maragheh Branch, Islamic Azad University, Maragheh, Iran.
}

\begin{abstract}
Bank duties in lieu of the cheque issuer are: non-payment of fund of the cheque in the written order of account owner, sending the second copy of the certificate of non-payment to the latest address of the account owner available at bank. Duties that a bank has in lieu of the cheque owner are : issuing non-payment certificate of cheque fund, non-payment of fund in the case of presenting written order of cheque owner, payment of fund of the in the case of requesting by the cheque owner, (if the bank balance is less than the fund on the cheque). These duties include disciplinary civil and penal guarantee, bank employee may excess the legal limitations in doing his law duties and commit actions that are known as crime in Islamic penal code, checking the crimes in public courts and it is done on the basis of criminal procedure, in the case that bank employee pay the cheque amount without corresponding the signature of the cheque issuer to the existing sample signature in bank or without noticing the order of non-payment ., it has civil responsibility, and the damage must be compensated . Bank employees are responsible to regard the bank inner regulations in addition to regarding the common laws of the country and breaking these regulations creates disciplinary responsibility for them.
\end{abstract}

Keywords: Bank, current account opening, obtaining customer identity by bank, closing current account of the cheque issuer, fair respite, issuing non-payment bill.

\section{INTRODUCTION}

In Iran's law system, all the institutes and their staff are responsible for carrying out their actions and have duties in lieu of people. Bank is also not an exception to this rule, because bank has different duties in lieu of owner and issuer of the cheque and sometimes duties resulted from it, encounter with ambiguities. We want to express that what duties bank has before the owner and issuer of the cheque; meanwhile, whether these duties contain executive guarantee or not? In law articles 3 and 14 of issuing the cheque law, bank is responsible before the cheque owner with these duties including issuing the bill of non-payment of the bank, payment of the cheque fund with the order of cheque owner in case that cheque fund has a less balance. The cheque owner presents the order of its nonpayment to the bank especially when the cheque is lost or stolen, but the bank encounters with ambiguities in doing such duties, because the bank must refuse paying the cheque fund on the basis of the beneficiary demand, and the beneficiary is the cheque owner and on the other hand the 
cheque is not in control of the mentioned person and there is no way for the bank to prove the truth and falseness of its claims, so if a person claims to be beneficiary of a cheque and with the claim to its lack, give the order of "stop payment", it is not clear that whether the bank take that order into consideration or not. In such an assumption, according to the article 14 of cheque issuing law cannot accompany the approval of the account owner from demand owner. Furthermore, article 14 does not have a correct and proper sanction for issuing antifact order because it has known the orderer not only for conviction to the given punishment but also has charged him to compensate the damage to the cheque owner (BAZGIR, 1996).

\section{THE CONCEPT OF TRADE DOCU-MENTS AND ITS IMPORTANCE:}

According to the role and job of trade, we notice that the community of merchants are separate from other imaginable communities and has a specific way and considering enormous dealings of merchants who think of only major contracts, so two basic needs are felt: security and speed; and trade contracts are distanced from civil transaction and payment instruments in civil position. Document in trade exists from civil law framework and a new existence system is felt from it. It exists from its paper condition which is as a prove instrument and this document which has no independence in civil law framework obtains abstraction description in trade law and takes some advantages and separates it from simple description of regular documents in civil law (NABAVI, 1997).

It is true that trade document is a part of ordinary document (according to civil law) but we say that it has a basic role in trade law and takes a specific value and mostly, this trade document creates a lot of responsibility for signatories which causes considerable ease in doing transactions. So, this document can be examined in different frameworks.

1. It creates the ease of economic turnover for merchants

2. It creates security

3. Those who sign it, are responsible.

The discussion of being joint liability of responsibility is an important matter which completely separates a trade document from an ordinary document. Which guarantee is better than the fact that the owner of trade document "although it is an ordinary document" can easily lodge a complaint against issuer, endorser, and so on. While such a thing does not exist in any place of the civil document (ordinary) and even being conveyed from one person to another, these documents qualifies the value of transferring the original estate (KATOOZIAN, 1985).

Trade document in its general sense includes bill, promissory note and cheque warehouse receipt, company shares, and so on, and in its strict sense includes bill, promissory note and cheque.

One of the contemporary jurists defines trade documents as follows:

"Trade documents in its strict sense are documents that trade law regards special advantages for them"(ABBASI, AND MIRHOSSEINI, 2004).

Another professor expresses trade documents as: They are documents that can be transacted and referee to a debt with short period maturity (ABBASI, AND MIRHOSSEINI, 2004). 
Dr. Amir Hossein Fakhari (1995), defines trade documents in its strict sense as the documents that are transactional and in favor of the owner of that referee to a debt with a short period maturity and these documents are usually used for commercial dealings (ASGHARI, 2006).

Another jurist defines trade documents as: Trade documents in its strict sense are documents that are transferable and comprise payment of specified amounts with viewing or in a short period maturity that is used as a payment Instrument instead of money and follow some legal special advantages.

\section{THE MEANING OF CHEQUE IN TRADE LAW}

According to article 310 of trade law, cheque is a piece of writing due to which the cheque issuer return or hand over completely or partially the funds in drawee in condition that the cheque includes stipulated requirements in article 311 and moreover, as it was mentioned in article 312, payable in favor of bearer or to the account of a certain person or to the order of a bank, and in any case cheque is a document that is transferred to another person as soon as its endorse is signed. According to the article 313 of trade law, legislator knows cheque as a cash document and expresses that : cheque fund must be acted as soon as it is presented but with this description and credit that observes cheque as a valuable and economic document, however emphasizes in article 314 that issuing cheque even though from one place to another once is not originally considered as trade action although regulations related to the guarantee of issuer and endorser and regu- lations related to protest and lodging a complaint and guarantee and cheque getting lost is the same as appointed in Browat items (HAMIDI, 1965).

So, it can be said that legislator's opinion of passing the above mentioned regulations is that cheque is a document of payment and a total of transfer and contains legal backing, in other words, valid and having more guarantee by endorsers but issuing the cheque is not considered as a trade act and the cheque issuer cannot be thought as a merchant because it is inferred from article 2 of trade law which is about the statistics of trade dealing that legislator has not regarded issuing of cheque on behalf of individuals as trade dealings., and following the mentioned action, he knew the cheque issuer as a merchant and executed the regulations related to merchants and the credit of their trade offices and also regulations related to merchants bankruptcy considering cheque issuers and their offices (SADEGHI, 2002).

\section{BANK DUTIES IN LIEU OF ACCOUNT OWNER AND CHEQUE OWNER}

\section{Obtaining customer status by custom- er's financial standing}

One of the most important duties of the bank is to identify the customer's financial standing and his credit. In fact, the matter is that whether the customer has enough action accuracy and financial ability to pay his issued cheques or not?

According to the mentioned laws, Iran's legislator is the criteria for identifying the credit and financial standing, lack of the existence of bank financial mis-performance on the behalf of the customers, that is; those whose names are not in the list of the 
subject of article 3 of the regulations, but research in this matter makes it clear that the legislator's point of view is that the discussed individuals have already opened an account turn out to have bad account and does not express the assumption that bank faces the applicant demand of account opening for the first time.

Can we make the bank get the information from central bank or not in the assumption that the person is applicant for opening an account? Answering this question is essential. In fact, if we know the bank accountable, lack of getting information from it, while opening account for customer causes his responsibility and causes him to compensate the damaged person. In our opinion, since a certain law has not made the banks responsible, a mere lack of getting information at the time of opening an account cannot be considered as a justification for knowing the bank responsible. Of course, caution commands that bank does such an action, at least to make sure to some extent that the applicant person lacks any financial mis-performance (SKINI, 2000).

\section{BANK DUTIES RELATED TO THE ACCEPTANCE OR REJECTION OF THE DEMAND ACCOUNT OPENING}

Bank duties related to the acceptance or rejection of the demand account opening is that if customers whose debt payment is essentially done by the bank with opening a current account, bank cannot refuse establishing the current account for such people without any legal sanction but except in some exceptional cases bank is not responsible for opening an account. According to the theory of freedom of the will, the con- tract of current account opening follows the general rules of contracts because both parties to an agreement must be satisfied (article 190 of civil law). So we conclude that bank is not responsible for the conclusion of the agreement of opening current account. So each of the state banks has the right to refuse opening a current account for each of the applicants, but on the other hand, it seems that they refuse the applicant with forties doctrine of the constitution but in some cases, bank is responsible for opening an account, specially government staff must open an account for their salary payment. So bank compulsion is limited to opening an account for applicant does not include one group. When bank concludes an agreement with the customer with its own satisfaction and agreement and presents a cheque book to an applicant, later it cannot claim to return it. The bank is allowed to cancel the agreement between itself and the customer when the requirements of article 21 of cheque law and article 4 of regulations are provided.

The task of central bank starts when judicial authorities in executing note under article 3 of regulations, send him needed information after issuing the bill of indictment. Execution of regulations of article 3 of regulations in sending the content of specifications of individuals for whom bill of indictment has been issued, may guarantee this mistake that uninformed banks may open a current account for them and deliver them cheque book until list of individual names arrive to different banks that is done at the end of each month. Let's suppose that judicial authority issues bill of indictment against issuers at the beginning of the month and presents his name and specifications to the central bank at the fifth of the 
month. The central bank only at the end of this month, presents the specifications of this individual to the banks of country, this person can open an account and get a cheque book in one or several banks until the content of the specifications of the subject of article 3 of regulations arrives. Such faults have caused the central bank to send in action, the content of the mentioned specifications continuously and due to the information, once a week instead of once a month to the banks. In order to inform the banks, the central bank has created circles titled as "information department of central bank" that carries out this duty of the bank optimally.

\section{BANK DUTIES IN LIEU OF CHEQUE ISSUER}

We said that bank actions considering current account and payment of the fund of issued cheques by customer, are in fact done on behalf of the customer and account owner by proxy. Now, the question is that if the account owner attempts to issue a cheque and deliver it to the customer, can he refuse paying it after issuing the cheque?

There are two law texts on the order of not paying the cheque fund by the customer: the first one, article 3 , and the other, article 14 of the law of cheque issuance.

1. Article 14 of the law of cheque issuance expresses that: The issuer of cheque or the beneficiary of their legal deputy director specifying that the cheque is lost or stolen or forged or has obtained through defraudation or breach of trust or other crimes, he can give the written order of non-payment of the fund to the bank. Bank can refuse paying its fund after establishing of the identity of the orderer and in the case of presenting the cheque, bank issues and delivers the certificate of non-payment, mentioning represented reason, cheque owner can complaint against those who have given the order of stop payment and whenever it is proven against the claim that has caused non-payment, the orderer will be committed not only to the punishments appointed in article 7 of this law but also to the payment of all the damages of the cheque.

Note 1 . The beneficiary related to this article is the person who the cheque is issued or endorsed to his name (or cheque is issued and payable in favor of his bearer). In cases which the order of non-payment has issued according to this article, bank is responsible to keep the cheque fund in a blocked account until it is suggested the proper course to pursue in forum or until the orderer withdrawal.

Note 2. The orderer must deliver his complaint to the judicial authorities and deliver the certificate of complaint to the bank at most at the period of one week. Otherwise, after the expiry of the mentioned time limit, bank pays its fund from the place of stock to the demand of the cheque owner.

Note 3. Paying the travelers and certified cheques cannot be stopped unless the issuer bank claims that it is a forged one. In this case, the right for the cheque owner to complain to the judicial authorities according to the purport of the latest part of article 14 will be maintained.

Issuance of the order of non-payment of the subject of article 14 is dependent on several conditions:

a) Cheque is obtained or lost because of one of the crimes.

b) The issuer or their legal deputy director specifying that cheque is obtained or 
lost with one of the crimes, should give the written order of non-payment to the drawee bank.

c) The orderer must deliver his complaint to judicial authorities after proclamation to the bank and present its certificate to the bank at most during one week. In this case, bank will refuse paying the cheque fund until it is suggested the proper course to pursue in forum and proclaim to the bank.

\section{SANCTIONS ON BANK DUTIES IN LIEU OF CHEQUE OWNER AND ISSUER}

\section{Concept of civil liability}

Although jurists have presented various definitions from civil liability of the government, in a general totaling, it can be said that civil liability of the government is that: responsibility resulted from the government acts whether the responsibility is on the basis on fault or not, whether it is because of administrative system deficiency and with the mistake of human factors. It is obvious that personal fault of government staff, is out of the content of this definition and is an exception and on this basis, the structure of legal laws of the country should accept the government civil liability clearly in order for the citizens to vindicate their citizenship rights relying on such rules because with the growing development of technology and side effects resulted from it, the citizens face undesirable crisis resulted from exclusive services of the government, which must be compensated with clear legal strategies in order for the society to be safe from its harmful economic and social results.

\section{ADMINISTRATIVE RESPONSIBILITY OF BANK STAFF}

Any society, institute, company or generally juridical entities or real persons have to inevitably employ people to do his affairs and bank which is a financial institution is not an exception to this.

Banks are inevitably forced to employ human forces in order to do its affairs. At the time of employment, a relationship is created between bank and employees which is resulted from a contract either about state banks which follow employment regulations of state banks system approved by council of ministers in $26 / 11 / 2008$ or about private banks which follow the law of labour and the contract between them.

Bank staff take actions in doing their handed over duties on the basis of the law or contract between them. Revocation from each of them may cause damages to the bank or customers. In this chapter, one section has been allocated to the bank employee duties on the basis of the determined law and other section has been allocated to bank staff liability which is generally resulted from non-observance of law.

Learners in this chapter learn that what duties are upon them according to administrative law, and in the case of nonobservance of law, what problems will be its result for him and the bank. More knowledge and identification about the administrative law and its related rules can increase improvement and safety of the work and then decrease damages and breaches and comprise job security for the employees. Employee duties: inferred from article 54 to 59 of State Civil Service Act, and also items mentioned in articles 42 and 43 of the sixth chapter of employment regulations of state bank system approved in 2008. 


\section{THE MOST IMPORTANT DUTIES AND TASKS OF BANK EMPLOYEES ARE:}

1. Employment in a personal way: The employee cannot determine a representative for doing his administrative duties.

2. Full employment: Employee is under the control of the department in all the administrative time and does not have the right to do another job during the time of the department.

3. Employment continuously: Employee is charged to do his legal duties constantly and avoid doing any kind of activity that causes the department to be off and disordered. So, employee does not have the right to be away from service without taking a leave (whether daily or hourly) or without any acceptable excuse such as disease and commission. In the same way, before acceptance of resignation, it is considered as unjustified absence and it is administrative breach.

4. Regarding rules and regulations: Employee is charged to regard the rules and regulations and not to violate its limitations in doing his duties. Lack of regarding the regulations or offence against them create strongly liability for the employees and also his obeyed organization that may be criminal, legal and administrative (disciplinary breach) according to the case.

5. Observance of administrative hierarchy: which means employee's obedience from the superior's orders, this is one of the most important doctrines of the organization because it is supposed that the superior is responsible for better management of the affairs and doctrine of liability necessitates that he has the needed power for the management of affairs and tasks are done with his opinion and according to the order.

Question: If the order of superior is against the rules and regulations, what should an employee do? Employee is charged to inform the superior official of the contradiction of the order to the rules and regulations in writing, if the superior official confirmed the execution of his order in writing after his notice, the employee is charged to execute the issued order. (Inferred from article 54 of State Civil Service Act).

Notice: Since recognizing the orders of superior to be legal or not is not a simple and clear especially for low-experienced employees, it is extremely recommended for the employee that in the case of occurrence of doubt and suspicion, advice should be done with experienced colleagues. Since employee is not allowed to refuse carrying out the orders of superior for any occasion and more recognition of himself.

6. Maintaining administrative secrets: Employee is charged to maintain the secrets from two aspects: first, maintaining bank secrets and second, maintaining the secrets of customer, divulging of each of these secrets can cause to create different kinds of responsibilities for the divulger of the secret.

7. Lack of profiteering: A civil servant is not allowed to obtain illegitimate profits from his job position but he is charged to do his duties with optimal accuracy and with impartiality. Any kind of deviation from this doctrine causes criminal and disciplinary pursue of the employee.

\section{CONCLUSION}

Cheque having clear advantages in making the payments easy, is a kind of facilitat- 
ing instrument in taking others' property. This is due to the trust of most individuals to it rather than similar documents such as draft and promissory note. The main reason of this trust is the excellent traits of the bank that the public has the belief that bank has regarded the necessary precautions in presenting cheque book to the customers of current account, however, our legislator has not presented outstanding duties for bank in a series of regulations passed in order to avoid misusing of individuals' trust to cheque. It can be said that bank plays the role of probation officer and law-officer or administration of justice officers. Of course, in cheque issuance law approved in 2003, duties that bank has in lieu of cheque owner and cheque issuer, have been reckoned. First, with regard to bank duties in lieu of cheque issuer, for example, closing all the current accounts of some of the cheque issuers, according to article 21 of cheque issuance law, banks are charged to close all the accounts or individuals who have issued bad cheque more than one time and their prosecution has not led to the issuance of bill of indictment and does not open a current account for their names until three years. Meanwhile, if bank officials do not act to the above legal duty, they will be condemned to one of the punishments determined in article 9 of the law of examination to the administrative violations, and central bank is charged to maintain the individuals who have issued bad cheque and give the list of their names to all banks of country. With regard to article 3 of by-laws of determination of criteria and regulations related to individuals' deprivation of opening current account, Islamic Republic of Iran central bank is charged to receive list of specifications of individuals whose prosecu- tion resulted in issuance of bill of indictment in relation to issuing bad cheque and prepare list of names and specifications of individuals subject to amendatory article 21 of cheque issuance law and notify to the banks of country through a circular at the end of each month and with regard to article 4 of mentioned by-laws, banks are charged to close the current account of individuals whose names have been written in the list of individuals subject to amendatory article 21 of cheque law and refuse opening current account and giving cheque book to them at a legal period of time. There are two legal texts in connection with non-payment of cheque fund with the written order of cheque owner, and also on the order of not paying the cheque fund by the customer: the first one, article 3, and the other, article 14 of the law of cheque issuance.

a) Cheque is obtained or lost because of one of the crimes.

b) The issuer or their legal deputy director specifying that cheque is obtained or lost with one of the crimes, should give the written order of non-payment to the drawee bank.

c) The orderer must deliver his complaint to judicial authorities after proclamation to the bank and present its certificate to the bank at most during one week. In this case, bank will refuse paying the cheque fund until it is suggested the proper course to pursue in forum and proclaim to the bank. Also it has been mentioned in article 3 of cheque issuance law: cheque issuers must have cash money in drawee bank equivalent to the mentioned amount in the written date on it and must not discharge in a way, all or part of the money that bank has issued cheque to its credit or give the order 
of non-payment of the cheque fund. Another duty that bank has in lieu of cheque issuer and other officials of cheque is that bank must regard the requirements of cheque payment during the time of payment to some extent that banking practice can rely on those requirements of cheque payment. Some duties of bank is accuracy and examination of cheque based upon the fact that it has been arranged legally and correctly, especially the signature on the cheque must conform to the signature of cheque owner which is maintained before bank. Whenever the signature on the cheque does not conform to each other within the limits of banking practice, bank must avoid honoring the cheque, otherwise, it is responsible in lieu of cheque issuer. What is considerable here is that bank is not guarantor for the discovery of forging. In the case of being forgery of cheque and its payment by the related bank, the payer bank does not have any responsibility, unless every ordinary person can recognize its being forgery, then bank is responsible to compensate the damages sustained.

But duties which bank encounters in lieu of cheque owner are: At the time of the payment of cheque, which bank must pay to the cheque owner in the case of existence of venue of funds and whenever bank refuses paying it without any acceptable excuse will be responsible for the damages sustained to the cheque owner as if bank having the venue of cheque does not pay it to the cheque holder and after that, the venue of cheque is removed because of cheque owner bankruptcy and the cheque holder does not achieve his rights, bank is charged to compensate the damages sustained to the cheque owner, and or at the time of paying the cheque, legal formalities were regarded, in the case that bank has not regarded legal formalities of cheque payment, for example, according to article 316 of trade law, person who receives cheque fund, must sign and seal its endorse. Meanwhile, whenever cheque is payable in favor of bearer, however, bank must control the signature or seal on its endorse and whenever bank pays a cheque which has not signed or sealed in the above way, is liable and when cheque is issued payable in favor of bearer or a specified person, here bank is also charged to establish cheque owner's identity. Since due to the order of article 11 of cheque issuance law, bank must insert the identity of the first bringer in the endorse of cheque, can conform identity of the cheque bringer according to his identification folios with the contents of cheque endorse but if it doesn't take such actions it is still responsible. Another duty which bank has in lieu of cheque owner is that: In regard to article 4 of cheque issuance law, whenever cheque is not paid due to the reasons stipulated in article 3 of cheque issuance law, bank is charged to mention in a particular notice, the cheque specifications, complete address and identity of cheque issuer, or insert the reasons of non-payment clearly and sign and deliver it to the cheque issuer. In a particular notice, he must certify the conformity of issuer's signature or sample signature available at banking practice and or lack of its conformity on behalf of bank, bank is charged to forward the duplicate copy through registered or express mails to the latest address of account owner which is available at bank in order to inform the cheque issuer and mention the complete information of cheque owner in this notice. Duty which bank has in article 5 of cheque 
issuance law based on the fact that if credit balance of cheque issuer's account in bank is less than the cheque amount, on demand of cheque holder, bank is charged to pay the balance of account to the cheque holder the cheque holder presents remainder received amount on cheque endorse to bank, receives a testimonial from bank including specifications of cheque and amount paid. The mentioned testimonial is a substitute for the original cheque, again here, bank is charged to forward duplicate copy of the testimonial to the latest address available at bank to the cheque issuer in order to inform him, and insert complete information of cheque holder in that testimonial in order for the cheque issuer not to have any claim including legal and criminal later. Thus, study of the above subjects shows that legislator has not predicted certain regulations especially about banks accountability in lieu of the act of issuing bad cheque and expresses a general rule only in article 35 of bank and financial law which due to that "every bank is responsible and liable to compensate the damages sustained due to its operations. This general rule does not have a lot of difference with common rules of civil liability and is not an easy tool to identify the bank fault and its condemnation to compensate damages of bad cheque holders which bank's guilty customers have granted them. Even with this assumption that bank has made mistakes in choosing the customer to fear from bank compulsion to compensate completely the damages of bad cheque holders in order to force them to be more careful in choosing the customer. In the stage next to opening an account and delivery of cheque book to customers, banks are considered to have more efficient effect. So, it can be said that in legal system of Iran, bank cannot deprive the account owner of having an account without the order of judicial authority and merely because of bad cheque on behalf of cheque owner. Secondly, bank has no charge to deprive the issuer either of having a current account or of having a cheque book (article 4 of by-laws of determination of criteria, .......), In sum of way of treating of Iran's legislation, book has a merely executive role, that is; only the role of judicial officer or justice officers and is the executive of judicial decision.

\section{REFERENCES}

ABBASI, M \& MIRHOSSEINI, S H. Laws of administrative breaches. Law publications, 2004.

ASGHARI, N. Series of explanation of cheque laws. Andisheh publications, first edition, 2006.

BAZGIR, Y. Verdicts of High Court of Cassation in legal affairs. Third Volume, Ghoghnoos publications, First edition, 1996. HAMIDI, A. "A discussion on cheque law approved in 1965", Bar Association, spring 1965.

KATOOZIAN, N.Civil laws, Automatic guarantee-civil liability. Tehran, 1985.

NABAVI $R$, SEID A A. Law of cheque issuance and legal matters around it. Mizan publications, 1997.

SADEGHI, M M \& HOSSEINI, A. Exclusive punishment booklet, Shahid Beheshti university publications, 2002.

SKINI, R. "Considerations on civil aspects of bad cheque issuance. Quarterly of law point of views. Fifth year, 2000, 17-18, spring-summer. 
(c)

License information: This is an openaccess article distributed under the terms of the Creative Commons Attribution License, which permits unrestricted use, distribution, and reproduction in any medium, provided the original work is properly cited.

Article received on June 09, 2017.

Evaluated July 04, 2017.

Accepted on Jully 04, 2017.

Published on August 18, 2017.

How cite this article (ABNT):

MOHAMMAD, Abasat Pour; ABDOLLAHI, Mehdi; GHOLIZADEH, Hoshang Mola. Bank duties in lieu of account owner and cheque owner and its sanctions. Estação Científica (UNIFAP), Macapá, v. 7, n. 1, p. 21-31, jan./abr. 2017. 